\title{
IMPLEMENTASI KURIKULUM 2013 (TERPADU) DI RA BAITURRAHMAN BIMA CIREBON
}

\author{
Oleh : \\ Khairunnisa Ulfadhilah ${ }^{1}$, Nurlaela ${ }^{2}$, Sukiman $^{3}$ \\ ${ }^{1,2,3}$ Universitas Islam Negeri Sunan Kalijaga Yogyakarta, Indonesia \\ e-mail: 19204030052@student.uin-suka.ac.id, \\ 19204030051@student.uin-suka.ac.id,sukiman@uin-suka.ac.id
}

Diterima 26 Januari 2021, direvisi 31 Maret 2021, diterbitkan 1 April 2021

\begin{abstract}
Abstrak
Kurikulum merupakan pondasi penting dalam proses pembelajaran di RA Baiturrahman Bima Cirebon yang diawali dari perencanaan hingga penilaian. Pengembangan kurikulum disesuaikan dengan kebutuhan masyarakat dan berorientasi pada anak. Tujuan penelitian ini untuk mengetahui penerapan pengembangan kurikulum 2013. Metode yang digunakan dalam penelitian ini menggunakan pendekatan kualitatif deskriptif. Teknik pengumpulan data yang digunakan dalam penelitian ini menggunakan observasi untuk melihat secara langsung penerapan kurikulum 2013, wawancara untuk mendapatkan informasi yang lebih valid, serta dokumentasi. Teknik analisis data dalam pengamatan ini menggunakan reduksi data model Miles and Huberman agar mengambil data yang aktual dan penelitian ini menggunakan teknik triangluasi untuk menguji keabsahan data yang telah diperoleh. Hasil pengamatan ini bahwa pengembangan kurikulum 2013 di RA Baiturrahman Bima Cirebon sesuai dengan anjuran pemerintah yang sesuai dengan kurikulum yang dibuat oleh pemerintah.
\end{abstract}

Kata Kunci: Kurikulum, Pengembangan.

\begin{abstract}
The curriculum is an important foundation in the learning process at RA Baiturrahman Bima Cirebon which starts from planning to assessment. Curriculum development tailored to the needs of society and child-oriented. The purpose of this study was to determine the implementation development of the 2013 curriculum. The method used in this study used a descriptive qualitative approach. The data collection techniques used in this study used observation to see firsthand the implementation of the 2013 curriculum, interviews to obtain more valid information, and documentation. The data analysis technique in this observation is using the data reduction model of Miles and Huberman in order to retrieve the actual data and this research uses the triangluation technique to test the validity of the data that has been obtained.
\end{abstract}

Keywords: Curriculum, Development.

\section{PENDAHULUAN}

Era globalisasi ini banyak mengalami perubahan diberbagai bidang misalnya perubahan pada sistem pembelajaran. Pembelajaran sangat penting dalam kehidupan bermasyarakat, sebab pembelajaran dapat mengubah tingkat baik buruknya manusia. Semakin baik kualitas pembelajaran, maka semakin baik kemampuan untuk menyelesaikan permasalahan kehidupan yang dihadapinya. Salah satu pondasi pembelajaran adalah kurikulum. Problem yang timbul pada masyarakat dapat mempengaruhi sistem pembelajaran dalam lembaga. Kurikulum digunakan untuk 
menuntaskan problem-problem pada lingkungan sekitar (Ulla, 2017). Kurikulum dibuat agar mempermudah proses kegiatan belajar karena di dalamnya terdapat rencana, pelaksanaan dan penilaian (National Association for the Education of Young Children (NAEYC), 2009).

Pendidikan merupakan pegangan sangat penting dalam diri manusia agar manusia memiliki kualitas yang baik (Fauzi, 2013). Menurut Perni (2019) pendidikan ialah suatu hal yang sangat berharga bagi bangsa dalam meningkatkan kemampuan setiap warganya untuk melanjutkan jenjang berikutnya. Pendidikan untuk anak usia dini itu penting karena sebagai dasar anak untuk mendapatkan ilmu dan melanjutkan kejenjang berikutnya (Bagus et al., 2020). Kurikulum sangat berpengaruh dalam pendidikan karena dapat mengembangkan potensi pada diri siswa (Mulyasa, 2011). Kurikulum juga dapat dikatakan sebagai alat atau sarana untuk menghasilkan anak yang berkualitas (Ramli, 2012).

Seorang pendidik profesional perlu memahami prinsip pengembangan kurikulum dalam profesinya (Guo et al., 2020). Banyak dalam sebuah lembaga, guru tidak memiliki tujuan yang jelas dan itu mengakibatkan guru tidak profesional saat pembelajaran berlangsung, karena mereka mempunyai kebiasaan dan menganggap bahwa telah terjalin pendidikan saat sesudah mengajar (Mayne \& Dixon, 2020). Jadi, saat peserta didik memiliki kesulitan itu disebabkan oleh permasalahan kinerja pendidik dalam menjelaskan pelajaran kurang menciptakan pengalaman belajar sesudah materi pelajaran diinformasikan atau evaluasi dalam pembelajaran, maka kurikulum itu bermanfaat untuk memberikan dasar dan arahan pelaksanaan program pembelajaran serta tata cara mengajar, dan tidak cukup materi pelajaran saja, namun perlu mengeksplor dalam hal belajar (Elmetwali \& Amer, 2020).
Kurikulum kerap dijadikan acuan dalam sebuah lembaga sebagai materi pelajaran ataupun bahan pelajaran untuk dipelajari anak disekolah, ataupun rencana pelajaran. Menurut Hakim dorongan kegiatan belajar memiliki peran yang sangat penting saat kegiatan belajar berlangsung. Kurikulum adalah suatu pondasi penting dalam pendidikan, karena kurikulum merupakan suatu program yang disiapkan untuk anak didik. Kurikulum digunakan dalam dunia pendidikan, untuk memberikan ilmu pengetahuan perlu dicapai atau diselesaikan anak guna untuk mencapai suatu tingkatan atau ijazah. Menurut pendapat Hilda Taba bahwa isiisi pokok kurikulum terdapat tarah, isi, dan cara (Susanto, 2011). Selanjutnya, kata Ronald C. Doll adalah Kurikulum dalam sembuah lembaga merupakan isi dari proses, baik formal maupun informal yang disiapkan untuk peserta didik agar memperoleh ilmu pengetahuan, mengembangkan bakat, dan mengubah sikap yang diberi ilmu di lembaga (Ali Mudlofir, 2012).

Penjelasan di atas dapat disimpulkan bahwa kurikulum merupakan suatu rancangan untuk proses pembelajaran anak ketika disekolah, kurikulum merupakan peraturan pemerintah yang dibuat untuk pendidikan dalam suatu lembaga yang terdapat isi kurikulum mengenai isi tujuan, strategi untuk pencapaian pada anak, dan pegangan guru untuk memberikan materi pada anak ketika proses pembelajaran berlangsung dikelas.

Menurut Syamsyul Bahri dalam pengembangan kurikulum tugas utama pemerintah dalam mengantur maupun mengembangkan pendidikan setelah itu peran pendidik dalam merealisasikan kepada anak-anak di sekolah dalam jenjang pendidikan menyeluruh (Hasanah, 2015). Kurikulum dapat dikatakan sebagai seperangkat rencana pembelajaran yang terdapat langkah-langkah dalam pedoman belajar-mengajar. Kurikulum ialah merangkup semua, dan sudah tertera 
dengan begitu lengkap kemudian pendidik menerapkan pada anak-anak disekolah. Pendidik perlu menciptakan suasana pembelajaran yang menyenangkan bagi anak, mengasah bakat anak agar menjadikan anak muncul rasa percaya diri dengan begitu anak akan tidak malu ataupun sekolah ditunggu oleh ibunya ketika sekolah. Sebab masih banyak ditunggu oleh ibunya dan tidak banyak ibunya ikut kedalam kelas saat mengikuti proses belajar-mengajar dikarenakan anak masih ingin ditemani ketika sekolah.

Kurikulum yaitu komponen penting dalam pendidikan di Indonesia untuk mengaplikasikan kepada anak di lembaga sekolah, dan semua jenjang pendidikan. Sebelum dilakukan, dan diterapkan pada anak, Pendidik perlu meninjau ulang sebab untuk menyesuikan dengan kondisi setelah itu dilakukan uji coba kemudian penilaian untuk melihat tingkat keberhasilan dalam kurikulum. Kurikulum dalam bidang pendidkan mempunyai peranan menumbuhkan anak rasa cinta pada negara, nasionalisme. Kurikulum disusun untuk mewujudkan tujuan pendidikan nasional dengan mencermati sesi pertumbuhan siswa dan kesesuaiannya dengan area, kebutuhan pengembangan nasional, pertumbuhan ilmu pengetahuan serta teknologi dan kesenian, sesuai dengan tipe serta jenjang tiap-tiap satuan pembelajaran.

Pertumbuhan dalam dunia pendidikan mampu tingkatkan mutu dari anak didik untuk menjajaki perkembangan tersebut tentu perlu diiringi terdapatnya pengembangan kurikulum pendidikan. Tingkatkan kualitas anak didik dengan membiasakan kondisi di tiap-tiap sekolah. Kurikulum selaku substansi pembelajaran didalam pelaksanaannya mesti disesuaikan dengan kebutuhan anak didik keadaan sekolah, dan wilayah sekolah. Proses pengembangan kurikulum, mengaitkan kepala sekolah, pendidik, ataupun tenaga kependidikan yang lain. Seorang pendidik didalam mengarahkan modul pada anak didik wajib dimulai dengan perencanaan serta persiapan yang matang. Pendidik bisa sukses dalam melaksanakan tugasnya bagaikan pendidik apabila sanggup mengajar dengan arah tujuan yang jelas supaya bisa mendapatkan hasil yang ditargetkan, bahan-bahan yang hendak dianjurkan haruslah disusun secara sistematis serta rinci perbagiannya, untuk menunjang berhasilnya proses mengajar didalam kelas seorang guru pula perlu mempersiapkan alat-alat pendukung yang sekiranya dapat membantu proses mengajar serta sanggup tingkatkan uraian anak. Pendidik melaksanakan interaksi pembelajaran di dalam area sekolah haruslah secara sadar serta terencana, kerena didalam area sekolah telah terdapat kurikulum pembelajaran yang wujudnya tertulis. Kurikulum ialah ketentuan utama yang terutama untuk pembelajaran di sekolah, sehingga kurikulum tidak dapat dipisahkan dari dunia pembelajaran. Kurikulum memiliki peran sentral dalam segala proses pembelajaran. Kurikulum memusatkan seluruh wujud aktivitas pembelajaran demi tercapainya tujuantujuan pembelajaran. Kurikulum ialah sesuatu rencana pembelajaran, memberikan pedoman dan pegangan tentang tipe, lingkup, serta urutan isi, dan proses pembelajaran. Di samping kedua guna itu, kurikulum juga merupakan sesuatu bidang riset yang ditekuni oleh para pakar ataupun spesialis kurikulum untuk pengembangan kurikulum bermacam institusi pembelajaran.

Kurikulum merupakan pondasi paling penting dalam sebuah lembaga karena di dalam kurikulum terdapat capaian-capaian pembelajaran atau pendidikan, agar menciptakan para peserta didik yang berkualitas (Han \& goleman, daniel; boyatzis, Richard; Mckee, 2019). Fungsi pengembangan kurikulum yaitu untuk terbentuknya sikap dan bakat peserta didik agar menjadi anak yang berkualitas, beriman, bertaqwa, berakhlak baik, memilki ilmu yang bermanfaat, dan mandiri. Salah satu komponen penting dalam sebuah lembaga adalah guru karena 
tanpa ada guru, tidak akan pernah ada peserta didik yang berkualitas.

Menurut Hamalik, jika kurikulum merupakan suatu rancangan yang dibuat oleh pemerintah untuk seluruh lembaga pendidikan agar sebuah lembaga pendidikan memiliki perencanaan pembelajaran, isi, dan tujuan untuk menciptakan atau mengembangkan peserta didik yang berpotensi (Redhiana, 2014). Menurut (National Association for the Education of Young Children (NAEYC), 2009). Kurikulum terdiri dari pengetahuan dan keterampilan yang akan diperoleh siswa dalam program pendidikan serta rencana pengalaman yang akan digunakan untuk pembelajaran anak. Jadi dapat disimpulkan kurikulum merupakan pondasi yang berperan penting dalam sebuah lembaga pendidikan karena didalam kurikulum terdapat perencanaan pembelajaran, isi, dan tujuan dalam mencerdaskan anak bangsa.

Pendidikan anak usia dini merupakan pendidikan yang paling utama karena anak usia dini merupakan masa golden age yang layak didukung untuk distimulasi tumbuh kembang anak, agar anak memiliki pertumbuhan dan perkembangan yang baik sesuai tahapannya (Yati \& Yaswinda, 2019). Maka kurikulum untuk pendidikan anak usia dini, pemerintah harus merancang atau membuat perencanaan pembelajaran, isi, dan tujuan yang matang untuk dikembangkan oleh sebuah lembaga dan pemerintah harus benar-benar memfasilitasi kebutuhan yang memadai agar sebuah lembaga pendidikan khususnya lembaga pendidikan anak usia dini dapat mengembangkan potensipontensi yang terdapat pada diri anak usia dini sehingga anak dapat tumbuh dan kembang dengan baik sesuai tahapannya. Setiap lembaga saat mengembangkan kurikulum pasti memilki hambatanhambatan misalnya pada peningkatan kemampuan pada siswa-siswanya, dan guru yang harus profesional (Haslip, Michael J., \& Gullo, 2017).Dari pemaparan diatas dapat disimpulkan bahwa kurikulum memiliki peranan penting untuk pendidikan karena kurikulum merupakan acuan yang terdapat perencanaan pembelajaran, isi, dan tujuan pendidikan untuk sebuah lembaga. Dengan demikian tujuan penelitian ini untuk mengetahui dasar, prinsip, dan faktor pengembangan kurikulum menurut Kurikulum 2013, dan mengetahui penerapan dasar, prinsip, dan faktor pengembangan kurikulum dalam pendidikan anak usia dini.

\section{METODE}

Penelitian ini menggunakan pendekatan kualitatif. Penelitian ini dilakukan di RA Baiturrahman Bima Cirebon. Teknik pengumpulan data dalam penelitian ini menggunakan teknik wawancara, dokumentasi, dan observasi. Peneliti mengumpulkan data dengan melakukan kunjungan langsung disekolah RA Baiturrahman Bima Kabupaten Cirebon, pengamatan ini juga melakukan pengamatan dengan wawancara terstrukturyang di dalamnya berisi pertanyaan untuk kepada kepala sekolah, dan guru kelas mengenai penerapan dasar, prinsip-prinsip, dan faktor pengembangan kurikulum di RA Baiturrahman Bima Kabupaten Cirebon. Selain itu, menggunakan dokumentasi untuk menambah informasi dalam penelitian atau untuk melengkapi data.

Peneliti menganalisis data menggunakan reduksi data model Miles and Huberman yaitu merangkum, memilah, dan memfokuskan data mana yang penting, sehingga memudahkan peneliti untuk mengumpulkan data selanjutnya dan peneliti akan mengolah data tersebut dengan mengkategorikan data yang perlu dimasukkan yaitu tentang dasar, prinsip-prinsip, dan faktor pengembangan kurikulum di RA Baiturrahman Bima Kabupaten Cirebon terkumpul dalam berbagai bentuk, secara berkesinambungan peneliti mengolah datadata tersebut dengan cara merangkum, 
membuat kategorisasi berdasarkan fokus penelitian, serta memilah hasil mana perlu dimasukkan dan hasil mana yang perlu dibuang yang tidak sesuai dengan pengamatan. Teknik keabsahan data yang digunakan dalam penelitian ini menggunkan teknik triangulasi.

\section{PEMBAHASAN}

Hasil yang didapatkan dalam pengamatan yang dilakukan di RA Baiturrahman Bima Cirebon mengenai dasar, prinsip, dan faktor pengembangan kurikulum mengacu pada kurikulum yang sudah ditetapkan oleh pemerintah karena dasar kurikulum adalah acuan berdirinya sesuatu yang berfungsi memberikan arah tujuan yang akan dicapai. RA Baiturrahman Bima Ciebon sangat memperhatikan arahan dari pemerintah dalam hal dasar, prinsip dan faktor pengembangan kurikulum untuk anak usia dini yang akan diterapkan disekolah, dan sebelum menerapkan pada anak pendidik dan kepala sekolah meninjau telebih dahulu.

RA Baiturahman Bima Cirebon melakukan kegiatan pra pembelajaran (setting class), pendidik membuat suasana kelas menjadi beberapa area, pengaturan kelas untuk setiap harinya berbeda dengan tema dan topik yang dikaji pada setiap pertemuan pembelajaran. Kegiatan pendahuluan dilakukan seperti berdo'a bersama sebelum belajar, dilanjutkan dengan pemberian salam kemudian pendidik menciptakan suasana belajar yang menyenangkan lalu pendidik menjalankan tugas sebagai pendidik untuk memberikan bahan ajar. Pada tahap ini pendidik merancang bahan ajar yang tepat dilakukan oleh anak usia dini, kegiatan dilakuka pada kegiatan pendahuluan, pembelajaran inti, kegiatan istirahat dilakukan untuk memberikan waktu pada anak untuk makan bekal yang sudah disiapkan oleh orang tua, kegiatan ini dmanfaatkan untuk membina kebiasaan yang baik pada saat anak makan. Anak perlu dibiasakan mencuci tangan, berdo'a sebelum makan, dan tertib saat makan ketika disekolah maupun diluar sekolah. Kegiatan selanjutnya anak-anak dapat bermain dilingkungan seklah seprti bermain ayunan, prosotan, jungkitjungkitan atau bermain bak pasir. Pada saat bermain dilingkungan sekolah pendidik memantau aktivitas anak-anak agr dapat mengetahi perkembangan potensi kecerdasan interpesonal, dan kecerdasan intrapersonal seperti bermain bersama teman disekolah sebab pada saat itulah anak akan terlihat. Kegiatan penutup kegiatan akhir ini pendidik melakukan menunjukan hasil pembelajaran anak seperti mengulang kembali pembelajaran diawal, kegiatan ini dapat mengundang kesan anak saat belajar, diberi kesempatan untuk dapat mengemukakan rasa yang ingin disampaikan. Kondisi diatas digunakan oleh pendidik sebagai kegiatan evaluasi, dalam hal ini evaluasi diakhir pembelajaran serta melatih kemampuan, mengasah ingatan anak, selain itu pendidik dapat menilai perkembangan anak selama proses belajar mengajar.

Menurut Crow and Crow, sebagaimana yang dikutip oleh Oemar Hamalik yakni kurikulum adalah rancangan pengajaran atau mata pelajaran yang disusun sistematis agar dapat menyelesaikan suatu program untuk memperoleh ijazah (Prasetyo \& Hamami, 2020). Dalam bukunya yang lain, Hamalik mepaparkan bahwa kurikulum memuat isi dan materi pelajaran (Hamalik, 2013). Jadi kurikulum adalah sejumlah mata pelajaran yang perlu dipelajari oleh anak untuk menambah ilmu, wawasan pada anak.

Menurut Alice Miel menjelaskan jika kurikulum meliputi keadaan sekolah, suasana sekolah, keinginan, keyakinan, pengetahuan agar dapat memberikan ilmu kepada anak. Kurikulum yakni fasilitas, kegiatan suatu lembaga pendidikan untuk mewujudkan visi, misi, dan lembaga sekolah. Sebab itu, pelaksanan kurikulum untuk menunjang keberhasilan sebuah lembaga perlu diperhatikan dalam tenaga 
kependidikan yang berkompeten, fasilitas yang menunjang, fasilitas bantu sebagai pendukung, adanya tenaga penunjang pendidikan seperti tenaga administrasi, operator, dan pustakawan. Adanya dana yang memadai, manajemen yang baik, budaya religius, moral, kebangsan, dan kepemimpinan yang visioner transparan, serta akuntabel.

Kurikulum mempunya fungsinya seperti program studi yakni mat pelajaran yang dipelajari anak ketika disekolah, kurikulum sebagai data atau informasi untuk bahan ajar yang diterakan pada anak, kurikulum yang kegiatan yang direncanakan agar dapat mendapatkan hasil yang baik, dan kurikulum sebagai pengalaman belajar dibawah naungan sekolah (Hamalik, 2013). Jadi dapat disimpulkan bahwa kurikulum seprangkat rencana pembelajaran yang terdiri dari isi, dan materi pelajaran yang terusun meliputi segala sesuatu yang dapat mempengaruhi perkembangan, dan pembentukan pribadi anak sesuai dengan tujuan pendidikan serta dapat meningkatkan mutu anak ketika disekolah maupun diluar sekolah.

Dasar pendidikan setiap negara berbeda, sebab perbedaan filosofi bangsa, budaya, dan lainnya. Berdasarkan Peraturan Menteri Pendidikan dan Kebudayaan Republik Indonesia Nomor 146 Tahun 2014 tentang Kurikulum 2013 Pendidikan Anak Usia Dini pasal 3 ayat 4, kerangka dasar kurikulum PAUD berisi landasan atau dasar filosofis, sosiologis, psiko-pedagogis, teoretis, dan yuridis yang mengacu pada Standar Nasional Pendidikan Anak Usia Dini. Secara lebih jelas, dasar atau landasan pengembangan kurikulum PAUD dijelaskan bahwa Dasar Filosofis adalah suatu dasar yang mementingkan pada pendidikan yang berakar pada budaya dan bangsa karena anak membutuhkan motivasi, keteladanan, penganyoman, dan perlindungan karena anak adalah pewaris yang kreatif yang harus dilindungi, Dasar Sosiologis adalah suatu dasar yang mementingkan pendidikan yang membentuk sikap anak untuk menghormati dan pilih kasih maka dari itu anak-anak membutuhkan pendidikan formal maupun informal dalam lingkungannya (Fauzi, 2013), Dasar Psiko-pedagogis adalah suatu dasar yang mementingkan pendidikan dalam pembentukkan perilaku atau sikap pada diri manusia itu sendiri. Perubahan perilaku pada manusia disebabkan karena kematangan pada diri manusia itu sendiri (Sukmadinata, 2014), Dasar Terotitis adalah suatu dasar yang memberikan pengetahuan ilmu sebanyak-banyaknya untuk peserta didik agar dapat meningkatkan keahlian atau bakat yang berupa perilaku, ilmu, dan bakat, Dasar Yuridis adalah suatu dasar yang berpacu pada Undang-Undang yang telah dibuat oleh pemerintah, dan Dasar Ilmu dan Teknologi adalah suatu dasar yang memiliki pengaruh sangat besar terhadap kemajuan ilmu pengetahuan dan teknologi yang berlangsung sangat cepat. Maka dari itu, pendidik adalah sumber yang berperan aktif saat kegiatan belajar dan mampu memanfaatkan llmu pengetahuan dan teknologi yang baik agar anak dapat memecahkan masalah dalam pembelajaran atau pendidikan sehingga peserta didik dapat mengimbangai dan mengembangkannya dalam kemaslahatan dan keberlangsungan hidup manusia.

Uraian di atas dapat menegaskan bahwa kurikulum dapat dikatakan sebagai modul pembelajaran yang wajib ditempuh dan dituntaskan oleh anak didik agar dapat menggapai tujuan yang sudah diresmikan karena kurikulum salah satu pondasi yang memiliki peran aktif pada sesuatu proses pembelajaran, disebabkan ia adalah pelengkap dalam menggapai arah pembelajaran dan sebagai acauan dalam penerapan pembelajaran. Dapat kita bayangkan bagaimana wujud penerapan sesuatu pembelajaran atau pengajaran di sekolah yang tidak mempunyai kurikulum karena didalam kurikulum terdapat guru yang telah dipersiapkan secara resmi dalam lembaga pembelajaran dalam suatu lembaga. Sehingga kedudukan guru dalam 
pengembangan kurikulum sangatlah penting. Berhubungan dengan itu, peran kurikulum dalam dunia pembelajaran di lembaga pendidikan sebab memiliki andil besar, yakni kurikulum merupakan bahan ajar pembelajaran sehingga apabila tidak terdapat kurikulum, proses belajar mengajar tidak akan menggapai tujuan dengan baik. Sebab didalam kurikulum berisi rencana pembelajaran bagaikan pedoman dan pula bagaikan bidang studi yang menjadi sumber konsep landasan untuk lembaga pendidikandalam proses belajar-mengajar. Hakikat pada kurikulum merupakan pedoman bagi pendidik untuk mengajar anak ketika disekolah, sebagai tuntunan seorang pendidik, dan di dalam kurikulum terdapat mengenai bahan ajar, suatu program pendidikan yang berisikan sebagai bahan pembelajaran, dan berupa pengalaman belajar diprogramkan, direncanakan lalu dirancangkan kemudian diterapkan serta diimplementasikan pada anak di RA Baiturrahman Bima Kabupaten Cirebon. Kurikulum mempunya peran penting dalam proses pembelajaran maupun pendidikan anak, maka dari itu proses pembelajaran anak perlu ditata ke dalam kurikulum, dan menyesuaikan dengan kebutuhan yang diperlukan agar dapat diterapkan pada anak di RA Baiturrahman Bima Kabupaten Cirebon.

RA Baiturrahman Bima Cirebon mempunyai prinsip-prinsip pengembangan kurikulum yang sudah dibuat oleh pemerintah, dan diterapkan disekolah. Prinsip di RA Baiturrahman Bima Cirebon sesuai yang dianjurkan oleh pemerintah, dan berdiskusi dengan tenaga kependidikan beserta kepala sekolah agar maksimal ketika diterapkan pada anak didik. Kurikulum pada jenjang anak usia dini berbeda dengan kurikulum dengan jenjang pendidikan lainnya, pencapaian pada kurikulum di RA Baiturahman Bima Cirebon yakni aspek perkembangan anak sesuai denga tingkat usia anak, dan aspek perkembangan yang akan anak capai seperti nilai moral dan agama, sosial emosional, kognitif, fisik motorik,bahasa, dan seni. Prinsip-prinsip di RA Baiturahman Bima Cirebon yani berpusat pada perkembangan anak, menerapkan kemandirian, disiplin anak agar dapat membentuk karakter anak, belajar dari lingkungan alam sekitar seperti field trip ke alam untuk outbond, belajar dan bermain dari lingungan sekitar seperti memanfaatkan belajar serta bemain dihalaman sekolah yang cukup luas, dan terdapat tanaman hijau, memanfatkan bahan ajar yang mudah serta murah dengan memanfaatkan barang bekas yang dapat dijadikan Alat Permainan Edukatif (APE), dan pembelajaran mengunakan pendekatan tematik salah satu metode pembalajaran agar dapat memberikan pengalaman langsung pada anak. Membangun kebiasaan berpikir pada anak sedari dini pendidik dapat merangsang kemampuan anak, dan pembelajaran inspiratif, menarik, kreatif serta inovatif dalam pembelajaran.

Penerapan kurikulum di RA Baiturahman Bima Cirebon dilakukan pembelajaran sesuai tema yang dibuat oleh pemerintah sesuai dengan tahapan perkembangan anak usia dini, dikembangkan melalui tema pembelajaran yang dilakukan setiap minggunya, dan sesuai dengan peraturan pemerintah yang berlaku. Lembaga pendidikan dituntut untuk menerapkan kurikulum disekolah kemudian diaplikasikan pada anak-anak didik, sebagai pedoman bahan ajar, dan dapat dikatakan sebagai akar, pondasi utama untuk melakukan proses pembelajaran ketika berlangsung. Kurikulum sudah dibuat oleh Kementerian Pendidikan lalu dikembangkan oleh pendidik, dan kepala sekolah. Selain itu, diperhatikan dalam tumbuh kembang anak, dan pengembangan sesuai dengan perkembangan anak.

Penerapan kurikulu di RA Baiturahim Bima Cirebon adanya penyusnan Program Semester (PROMES), Rencana Pelaksanaan Pembelajaran Mingguan (RPPM), Rencana Pelaksanaan Pembelajaran. Harian (RPPH), dan 
Perencanaan Penilaian. Kebrhasilan penerapan kurikulum berpengaruh pada pendidik sebab pendidik memiliki komitmen dalam menerapkan kurikulum. Kreativitas pendidik menentukan keberhasilan penerapan kurikulum dalam menyusun dokumen kurikulum, mampu menciptakan suasana belajar yang menyenangkan bagi anak didik, metode belajar menyesuaikan dengan kemampuan anak, melibatkan anak secara aktif agar anak dapat belajar rasa percaya diri, dan membuat rasa percaya diri pada anak sedari usia dini. Pendidik perlu menyusun serta meaksanakan evaluasi dalam perkembangan atau hasil belajar anak untuk menilai pelaksanaan belajar anak ketika disekolah.

Pada dasarnya kurikulum sebagai kriteria dalam belajar anak, kurikulum adalah recana program pendidikan yang telah diatur oleh Kementerian Pendidikan maka dari itu perlu ditinjau dalam aspek, dan penerapan kurikulum. Kurikulum di RA Baiturahim Bima Cirebon disusun sebagai pedoman pelaksanaan pembelajaran yang mempunyai peran dalam lembaga pendidikan anak usia dini, mempnyai standar untuk dikembangkan pada nak sesuai dengan kebutuhan anak didik di RA Baiturahim Bima Cirebon. Selain itu, alam penerapan kurikulum dapat disesuaikan dengan keadaan budaya dengan kehidupan sehari-hari.

Menurut Hamalik menyatakan bahwa mengenai prinsip pengembangan kurikulum perlu diperhatikan agar mengerjakan dengan optimal, dan menyeluruh (Hamalik, 2013). RA Baiturahim Bima Cirebon menerapkan sebagaimana prinsip pengembangan kurikulum sebagai berikut:

a. Prinsip Relevansi

Relevansi mempunyai arti tepat atau yang biasa kita sebut dengan cocok, apabila kurikulum mengacu pada prinsip relevansi wajib dicermati dalam hal ekstral seperti kurikulum mempunyai penilaian, tahapan, metode. Sedangkan internal ialah kemampuan anak dalam pembelajaran disekolah, menyediakan keperluan maupun fasilitas agar tersedia dan siap dipakai. Oleh karena itu pihak sekolah RA Baiturrahim Bima Cirebon merancang kurikulum namun perlu dicermati agar dapat menunjang kemampuan anak, dan menyesuaikan era jaman kini serba online menggunakan gadget sebab teknologi sudah sangat maju seta pesat. Agar dapat mencerdasarkan anak bangsa melalui kurikulum pembelajaran yang sesuai dengan anjuran pemerintah maupun Kementerian Pendidikan.

b. Prinsip Fleksibilitas

Pengembangan kurikulum di RA Baiturrahan Bima Cirebon berupaya agar hasilnya mudah, dan dapat diterapkan pada anak serta menyesuaikan suasana maupun tempat agar dapat terciptanya pembelajaran secara optimal untuk anak didik. Menerapkan kurikulum dalam prinsip agar menyesuikan dengan bakat anak, kurikulum juga perlu memberikan tempat untuk keluwesan pendidik agar dapat memperluas minat anak, serta melengkapi fasilitas di sekolah.

c. Prinsip Kontinuitas

Keterkaitan dalam kurikulum di RA Baiturrahman Bima Cirebon dalam halnya proses pembelajaran yang telah diatur oleh kurikulum bahwasanya perlu meninjau keterkaitan baik dalam proses belajar anak di sekolah maupun belajar ketika di rumah. Makna kontinuitas merupakan berkaitan dengan kurikulum dari berbagai jenjang pendidikan di Indonesia, selain itu berkaitan dalam tingkat pendidikan, kurikulum dapat melengkapi bahan ajar lainnya.

d. Prinsip Efisiensi 
Kurikulum dikembangkan agar pendidikan tersusun rapi, begitu halnya dengan RA Baiturrahaman Bima Cirebon diperlukan untuk menyusun perencanaan dalam program belajar-mengajar yang sebagaimana sudah diterapkan pada anak-anak disekolah. Pendidik ketika menjelaskan pembelajaran depan anak-anak dikelas sebagai salah satu proses, ketika pendidik terdapat kurang maksimal dalam pengajar dilakukan mengikuti pelatihan, workshop, diklat, atau acara yang serupa. Aspek efektivitas anak dalam proses pembelajaran perlu mengikuti metode dalam kurikulum yang berkaitan dengan pembelajaran agar mencapai indikator pencapaian anak.

Sukmadinata memaparkan mengenai prinsip khusus meliputi prinsip penentuan tujuan pendidkan, pemilihan isi pendidikan, pemilihan proses belajar mengajar, pemilihan media, alat pengajaran, dan berkenan dengan penilaian penjelasan yakni (Sukmadinata, 2014):

1) Prinsip Penentuan Tujuan Pendidikan

Prinsip tujan pendidikan di RA Baiturahim Bima Cirebon yakni mencerdasarkan anak, menjadikan anak berakhlakul karimah, dan berkembang sesuai tahapan. Pembelajaran bertujuan meliputi sumbersumber; syarat, mensurvei anggapan warga mengenai kebutuhan warga, mensurvei perihal pemikiran warna mengenai sudut pandang dalam hal sumber daya manusia.sebabsumber daya manusia kini terkikis dengan tenologi yang canggih bahkan terdapat beberapa negara tenaga manusia sudah tidak dibutuhkan, dan beralih pada robot untuk membantu segala kebutuhannya.

2) Prinsip Pemilihan Isi Pembelajaran Kurikulum Memastikan bagian kurikulum, perlu diperhatikan dalam mempertimbangkan landasan yakni dibutuhkan penjelasan pembelajaran, perilaku, keahlian pada anak untuk pemilihan isi pada kurikulum dilakukan oleh pendidik mana yang tepat diterapkan pada anak di lingkungan sekolah maupun di luar sekolah sebab terdapat beberapa anak yang dikelas mempunyai kepribadian yang diam, dan tidak mau bersosialisasi dengan teman bahkan hanya mau dengan ibunya saja.

3) Prinsip Pemilihan Proses Belajar-Mengajar

Dalam proses belajar-mengajar sebaiknya mencermati hal-hal seperti persamaantahapan dalam menyampaikan materi untuk mengajarkan bahan pelajaran, tata cara maupun metode dalam proses pembelajaran ataupun perbandingan orang tua anak didik dalam keefektifannya.

4) Prinsip Pemilihan Media serta Perlengkapan Pembelajaran Menunjang pembelajaran anak didik seperti efektivitas media pembelajaran, interaksi pendidik dengan anak didik sangat berpengaruh dalam proses pembelajaran dilakukan, ketersediaan media pembelajaran dengan membuat sendiri dari bahan-bahan bekas seperti kardus bekas yang dapat bermanfaat dalam bahan ajar anak, dan pendidik 
menstimulasi

menggunakan

anak

pembelajaran.

5) Prinsip Berkenaan dengan

Penilaian

Prinsip penilaian hasil belajar anak dapat dilakukan dengan penilaian hasil belajar harus sesuai, berorientasi pada pencapaian kompetensi, objektif, berkesinambungan, dan menyeluruh.

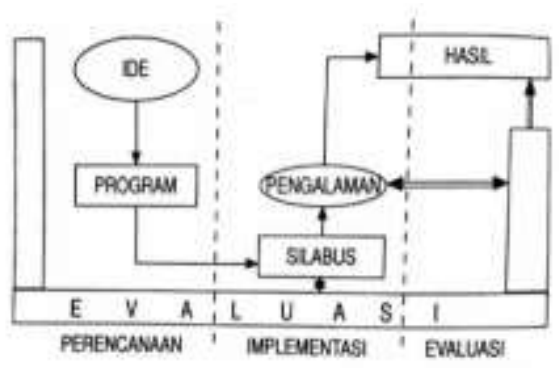

Gambar 1. Proses Pengembangan Kurikulum

Bagan yang sudah dipaparkan mengandung makna yaitu proses pengembangan kurikulum sampai penilaian, proses pengembagan kurikulum meliputi perencanaan, impelementasi, dan penilaian. Wujud pengembangan kurikulum sesuai dengan jenjang lembaga pendidikan anak. Menurut Hamalik proses penembangan kurikulum diterapakan pada anak-anak diawali yang terbaik. Berdasarkan riset penerapan kurikulum dengan merata kemudian dilakukan peninjauan agar dapat optimalisasi dalam kurikulum di RA Baiturrahman Bima Ciebon.

Tedapat hambatan-hambatan pengembangan kurikulum di RA Baiturrahman Bima Ciebon terletak hambatan terdapat orang tua yang kurang menunjang anak ataupun minimnya memberikan stimulasi pada anak ketika dirumah, dan kurangnya fasilitas sebab setiap perubahan kurikulum, fasilitaspun akan mempengaruhi pengembangan kurikulum di RA Baiturrahman Bima Cirebon. Pengembangan kurikulum 2013 di RA Baiturrahman Bima Cirebon sesuai dengan anjuran pemerintah yang sesuai dengan kurikulum yang dibuat oleh pemerintah.

\section{SIMPULAN}

Hasil penelitian di RA Baiturrahman Bima Ciebon yakni adanya implementasi dasar dalam kurikulum dapat dikatakan sebagai modul pembelajaran yang diterapkan pada anak didik secara optimal. Selain itu, prinsip kurikulum di RA Baiturrahman Bima Ciebon terdapat beberapa kategori yakni prinsip relevansi merancang kurikulum, menunjang kemampuan anak, dan mengikuti perkembangan jaman. Prinsip flekbilitas hasil yang mudah kemudian diteapkan pada anak menyesuaikan dengan anak didik, prinsip kontuinitas berkaitan dengan kurikulum untuk meninjau ulang, prinsip efisiensi kurikulum yang berkaitan dengan pembelajaran agar mencapai indikator pencapaian anak. Faktor pengembangan kurikulum sebagai proses menyeluruh yang berkaitan kebijakan nasional di bidang pendidikan menyesuaikan dengan visi, misi, dan strategi pendidikan nasional.Pengembangan kurikulum 2013 di RA Baiturrahman Bima Cirebon sesuai dengan anjuran pemerintah yang sesuai dengan kurikulum yang dibuat oleh pemerintah.Tedapat hambatan-hambatan pengembangan kurikulum di RA Baiturrahman Bima Ciebon terletak hambatan terdapat orang tua yang kurang menunjang anak dalam halnya minim memberikan stimulasi pada anak ketika dirumah, dan kurangnya fasilitas sebab setiap perubahan kurikulum, fasilitaspun akan mempengaruhi pengembangan kurikulum di RA Baiturrahman Bima Cirebon.

\section{DAFTAR PUSTAKA}


Ali Mudlofir. (2012). Aplikasi Pengembangan Kurikulum Tingkat Satuan Pendidikan dan Bahan Ajar Dalam Pendidikan Agama Islam. Bandung: PT Remaja Rosdakarya.

Bagus, I., Sindu, K., Hindu, U., Gusti, N. I., Sugriwa, B., \& Disiplin, U. (2020). Meningkatkan Perilaku Disiplin Anak Usia Dini. 5(2), 169-179.

Elmetwali, M., \& Amer, M. (2020). The Impact of Distance Education on Learning Outcome in Computer Skills Course in Prince Sattam bin Abdulaziz University: An Experimental Study. 9(4), 1-9. https://doi.org/10.5430/jct.v9n4p1

Fauzi, I. \& S. (2013). Kurikulum dan Bahan Ajar PAUD: Untuk Guru PAUD, Dosen, dan Para praktisi Pendidikan. Jember: Studi Pemerdayaan Rakyat dan Transformasi Nasional.

Guo, J., Wu, C., Zhang, J., Xiao, H., Lv, S., Lu, D., ... Cao, Y. (2020). International Journal of Hygiene and Early life triclosan exposure and neurodevelopment of children at 3 years in a prospective birth cohort. International Journal of Hygiene and Environmental Health, 224(September 2019), 113427. https://doi.org/10.1016/j.ijheh.2019.1 13427

Hamalik, O. (2013). Proses Belajar Mengajar. Jakarta: Bumi Aksara.

Han, E. S., \& goleman, daniel; boyatzis, Richard; Mckee, A. (2019). 済無No Title No Title. Journal of Chemical Information and Modeling, 53(9), 1689-1699.

Hasanah, I. (2015). Kurikulum Pendidikan Anak Usia Dini. Konstruktivisme: Jurnal Pendidikan \& Pembelajaran, 7(2), 155-163. https://doi.org/10.30957/konstruk.v7i 2.314

Haslip, Michael J., \& Gullo, D. F. (2017). The Changing Landscape of Early Childhood Education: Implication for Policy and Practice. Association for
Childhood Education International Global Summit on Children. New York: Springer Science + Business Media.

Mayne, H., \& Dixon, R. A. (2020). The Epistemological Dilemma: Student Teachers Shared Experiences of Jamaica 's National Standards Curriculum ( NSC ). 9(4), 29-39. https://doi.org/10.5430/jct.v9n4p29

Mulyasa, E. (2011). Kurikulum Berbasis Kompetensi. Jakarta: PT Remaja Rosdakarya.

National Association for the Education of Young Children (NAEYC). (2009). Developmentally Appropriate Practice in Early Childhood Programs. New York.

Perni, N. N. (2019). Pentingnya Menciptakan Suasana Pembelajaran Bagi Anak Usia Dini. Pratama Widya : Jurnal Pendidikan Anak Usia Dini, 2(2), 45. https://doi.org/10.25078/pw.v2i2.101 5

Prasetyo, A. R., \& Hamami, T. (2020). PRINSIP-PRINSIP DALAM PENGEMBANGAN KURIKULUM. 8, 42-55.

Ramli, M. (2012). Pendampingan Perkembangan Anak Usia Dini. Jakarta: Departemen Pendidikan Nasional RI.

Redhiana, D. (2014). Pengembangan Kurikulum Pada Aspek Ilmu Pengetahuan Dan Teknologi Yang Berbasis Lingkungan Hidup Melalui Pendekatan Saintifik Di Sekolah Dasar. Jurnal Ilmiah Pendidikan Dasar Dinamika, 6(2), 215-234.

Sukmadinata, N. S. (2014). Pengembangan Kurikulum: Teori dan Praktek. Bandung: PT Remaja Rosdakarya.

Susanto, A. (2011). Perkembangan Anak Usia Dini. Jakarta: Kencana.

Ulla, M. B. (2017). T hai Learners Linguistic Needs a nd Language Skills: Implications for Curriculum Development. 10(4), 203-220. 
Yati, F., \& Yaswinda, Y. (2019). Penerapan Model Evaluasi CIPPO dalam Mengevaluasi Penyelenggaraan Lembaga PAUD.
Jurnal Obsesi: Jurnal Pendidikan Anak Usia Dini, 4(1), 30. https://doi.org/10.31004/obsesi.v4i1.2 38 